\title{
Aminoacylation of Barley Stripe Mosaic Virus RNA: Polyadenylate- Containing RNA has a 3'-Terminal Tyrosine-Accepting Structure
}

\author{
A. A. AGRANOVSKY, V. V. DOLJA, † V. G. GORBULEV, \\ YU. V. KOZLOV, $†$ AND J. G. ATABEKOV ${ }^{1}$
}

Laboratory of Bioorganic Chemistry, and Department of Virology, Moscow State University,
Moscow 1172s4, and †Institute of Molecular Biology of Academy of Sciences, Moscow, USSR

Received September 8, 1980; accepted March 6, 1981

\begin{abstract}
Barley stripe mosaic virus (BSMV) RNA which was previously reported to contain poly(A) sequences (Agranovsky et al., 1978) can be specifically esterified with tyrosine in vitro in the presence of an aminoacyl-tRNA synthetase fraction from wheat embryos. All the three RNA components of the BSMV strain with a three-component genome (Norwich) and both RNA components of a two-component strain (Russian) can be tyrosylated. The poly(A)-containing (bound to oligo(dT)-cellulose) and poly(A)-deficient (not bound to oligo(dT)-cellulose) fractions of BSMV RNA display a similar amino acidaccepting ability. The nucleotide sequence which accepts tyrosine is coupled with the intact genomic polyadenylated BSMV RNA. The viral RNA isolated after sucrose density gradient centrifugation under drastic denaturing conditions retains its aminoacylating activity, which suggests that this activity is not due to the presence in a BSMV RNA preparation of a tyrosine tRNA associated with BSMV RNA. Inhibition of aminoscylation of the 3'-oxidized (treated with sodium metaperiodate) BSMV RNA suggests that the tyrosine-accepting structure is localized at the 3 ' terminus of BSMV RNA molecules. It is shown that segments of different lengths obtained upon random fragmentation can be tyrosylated. The $3^{\prime}$-terminal (tyrosine-accepting) poly $(\mathrm{A})^{+}$segments can be isolated. The shortest segments of viral RNA capable of being aminoacylated [i.e., containing both tRNA-like structure and poly $(A)]$ consists of approximately 150-200 nucleotides. The analysis of the oligonucleotides derived from individual BSMV RNA components labeled with ${ }^{32} \mathrm{P}$ at the 3 ' end revealed two types of $3^{\prime}$-terminal sequences different from poly(A). It is suggested that a $\operatorname{poly}(A)$ sequence is intercalated between a $3^{\prime}$-terminal tyrosineaccepting structure and the $5^{\prime}$-terminal portion of poly(A) BSMV RNA.
\end{abstract}

\section{INTRODUCTION}

The ability of the virion RNAs of several viruses to accept specific amino acids in a mode similar to the aminoacylation of cellular tRNAs has been reported in the last decade (for review, see Hall, 1979; Atabekov and Morozov, 1979). Turnip yellow mosaic virus (TYMV) RNA can be esterified with valine in a reaction with aminoacyl-tRNA synthetase from $E$. coli (Pinck et al., 1970; Yot et al., 1970) as well as with a eukaryotic enzyme (Kohl and Hall, 1974). RNAs of bromo- and cucu-

\footnotetext{
'To whom all correspondence and reprint requests should be addressed.
}

moviruses accept tyrosine (Hall et al., 1972; Kohl and Hall, 1974); RNAs of common strain TMV (Oberg and Philipson, 1972), cucumber viruses 3 and 4 (our unpublished data), and $\mathrm{K}$ strain TMV all accept histidine, whereas cowpea TMV accepts valine (Beachy et al., 1976).

It has been shown that a tRNA-like structure is present at the $3^{\prime}$ end of some plant virus RNAs. The primary structures of the 3'-terminal fragments of TMV, brome mosaic virus (BMV) and TYMV RNAs which accept histidine, tyrosine, and valine, respectively, have been reported (for review, see Hall, 1979).

Surprisingly, the 3 '-polyadenylated vi- 
rion RNAs of picornaviruses have been found to also accept specific amino acids. RNAs of encephalomyocarditis (EMC) virus and mengovirus can be esterified with serine (Lindley and Stebbing, 1977) and histidine (Salomon and Littauer, 1974), respectively. Unlike the plant viruses mentioned above, picornaviruses seem to contain tRNA-like structures in the internal but not at the $3^{\prime}$-terminal region of their genomic poly $(\mathrm{A})^{+}$RNAs (Lindley and Stebbing, 1977).

Two additional phenomena illustrating different forms of virion-associated cellular tRNAs have been noted. Thus, virions of eggilant mosaic virus (EMV) (a member of the tymovirus group) were found to contain lysine-accepting 4 S RNA noncovalently bound to the viral genome (Pinck et al., 1974; Pinck and Hall, 1978). It has also been shown that cellular tRNA molecules serving as primers for reverse transcription are complexed with a specific site in the virion RNA of retroviruses (Randerath et al., 1971; Rosenthal and Zamechnik, 1973; Wang et al.; 1973). Firm binding of host leucine tRNA to MS2 virions has also been demonstrated (DiNatale and Eilat, 1976).

The object of the present investigation, barley stripe mosaic virus, has a functionally divided genome. An unusual feature of BSMV is its variability as a genetic system. The number of RNA components, designated as RNAs $1,2,3$, and 4, and having molecular weights of 1.40-1.50, 1.17$1.24,1.04-1.20$, and $0.93-1.05 \times 10^{6}$, respectively, varies from two to four in different BSMV strains (Jackson and Brakke, 1973; Lane, 1974; Palomar et al., 1977). Moreover, the proportion of genomic components in the same strain can be altered by the loss of RNA 3 and/or RNA 4-in the case of a four-component strain-by transferring of BSMV at high dilutions (Palomar et al., 1977).

It has been reported that the total BSMV RNA preparation represents a population consisting of poly(A) ${ }^{+}(60-80 \%)$ and poly $(\mathrm{A})^{-}(20-40 \%)$ molecules (Agranovsky et al., 1978). The 5' end of BSMV RNA is blocked with a cap structure (Agranovsky et al., 1979). The length of
poly(A) tracks in BSMV RNA was found to be 8 to 30 nucleotides with 19- to 28nucleotide fragments being predominant (Negruk et al., 1979). It was suggested that the poly(A) sequence is located at the $3^{\prime}$ end of BSMV RNA (Agranovsky et al., 1978). This conclusion should now be revised by our results presented below. Here we show the presence of a tyrosine-accepting structure in genomic RNA components of BSMV which is localized at the $3^{\prime}$ end of BSMV RNA and is separated from the 5 -originated part of the viral genome by a poly(A) tract. Both the tyrosine-accepting structure and the poly(A) sequence are contained within a 150- to 200-nucleotide piece of BSMV RNA.

\section{MATERIALS AND METHODS}

Reagents. $\left[\gamma^{32} \mathrm{P}\right] \mathrm{ATP} \quad(1500-2000 \mathrm{Ci} /$ mmol), tritiated amino acid mixture (TRK 440), [ $\left.{ }^{3} \mathrm{H}\right]$ alanine $(36 \mathrm{Ci} / \mathrm{mmol})$, $\left[{ }^{3} \mathrm{H}\right]$ arginine $\cdot \mathrm{HCl}(11 \mathrm{Ci} / \mathrm{mmol}),\left[{ }^{3} \mathrm{H}\right]$ aspartic acid $(273 \mathrm{mCi} / \mathrm{mmol})$, ${ }^{3} \mathrm{H}$ gglycine

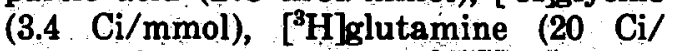
mmol $),\left[{ }^{3} \mathrm{H}\right]$ methionine $(2 \mathrm{Ci} / \mathrm{mmol}),\left[{ }^{3} \mathrm{H}\right]-$ phenylalanine $(4.2 \mathrm{Ci} / \mathrm{mmol})$, $\left[{ }^{3} \mathrm{H}\right]$ threonine $(439 \mathrm{mCi} / \mathrm{mmol})$, and $\left[{ }^{3} \mathrm{H}\right]$ tyrosine $(82 \mathrm{Ci} /$ $\mathrm{mmol}$ ) were from Amersham (England); pancreatic ribonuclease (RNase $A$ ), $U_{2}$ and $T_{1}$ RNase (Calbiochem and Worthington); oligo(dT)-cellulose (P-L Biochemicals and Sigma); N-succinylimidyl ester of 3(4-hydroxyphenyl)propionate (Pierce); unlabeled amino acids (Sigma).

Nucleic acids. The following BSMV strains were used: a two-component strain, Russian; a three-component strain, Norwich; and a four-component strain, Argentina Mild.

BSMV was propagated on wheat plants and isolated as described previously (Agranovsky et al., 1978). Brome mosaic virus (BMV) and TMV preparations were obtained from Dr. V. K. Novikov. The RNAs were isolated by phenol extraction from purified viruses and from Escherichia coli $50 \mathrm{~S}$ ribosomal subunits (Agranovsky et al., 1978).

The preparations of individual BSMV RNA components (Norwich and Russian 
strains) were isolated by a previously described method (Dolja et al., 1977).

Total tRNA from wheat embryos (Mironovskaya-808) was prepared by phenol extraction of S-100 supernatant, obtained essentially by the method of Zagorsky (1978). Preparation of poly (A) ${ }^{+} 10$ S mRNA from mouse plasmocytoma was kindly supplied by Dr. N. Sakharova.

Concentration determinations. The concentrations of BSMV and RNAs were determined spectrophotometrically. The extinction coefficients used were $E_{260 \mathrm{~nm}, 1 \mathrm{~cm}}^{0.1 \%}$ $=2.5$ for BSMV, and 25.0 for all the nucleic acids.

Preparation of synthetase fraction and aminoacylation conditions. Wheat embryo synthetases were isolated from S-100 supernatant, prepared as described previously (Zagorsky, 1978). Twelve milliliters of S-100 were applied at $+2^{\circ}$ to a DEAEcellulose column $(1.5 \times 30 \mathrm{~cm})$ equilibrated with the A buffer (10 $\mathrm{mM}$ Tris-acetate, $\mathrm{pH}$ 7.6; $8 \mathrm{mM}$ 2-mercaptoethanol). The column was eluted first with the $A$ buffer and then with $50 \mathrm{mM} \mathrm{KCl}$ in A buffer until the background level of absorption at $260 \mathrm{~nm}$ was obtained. The eluate was monitored in an ISCO Model UA-5 absorbance monitor. Elution of synthetases was performed with $0.25 M \mathrm{KCl}$ in A buffer. The peak fractions were collected, pooled, and dialyzed against 100-200 vol of the $A$ buffer for $3 \mathrm{hr}$ to remove the excess $\mathrm{KCl}$. All the above operations were carried out at $+2^{\circ}$. The final protein concentration of the synthetase preparations was $3.5-4.0 \mathrm{mg} /$ $\mathrm{ml}$, as determined spectrophotometrically $\left(E_{280 \mathrm{~nm}}^{0.1 \%}=1.6\right)$. The enzyme preparations were immediately frozen in liquid nitrogen and stored in $0.5-\mathrm{ml}$ aliquots at $-60^{\circ}$. Only a slight decrease in activity was noted after 6 months of storage.

The RNAs were aminoacylated essentially as described by Kohl and Hall (1974), using a mixture consisting of $50 \mathrm{mM}$ HEPES-KOH, pH 7.6; $1 \mathrm{mM}$ ATP; $2 \mathrm{mM}$ dithiothreitol; $40 \mathrm{mM} \mathrm{KCl} ; 5 \mathrm{mM}$ magnesium acetate; 5-10 $\mu \mathrm{g}$ RNA; 80-100 $\mu \mathrm{g}$ synthetase preparation, and $0.5-10.0 \mu \mathrm{Ci}{ }^{8} \mathrm{H}$ amino acid(s). The total volume was 100 $\mu l$ and the incubation time was $30 \mathrm{~min}$ at $30^{\circ}$. The samples were spotted onto a filter paper for determination of radioactivity bound to RNA. When tyrosyl-BSMV RNA was to be recovered, the reaction was scaled up to as much as 200-400 $\mu$. The reaction was terminated by the addition of $15 \mu$ l of $2 M$ sodium acetate buffer, $\mathrm{pH}$ 5.0 , and $0.5 \%$ SDS. This was followed by one or two cycles of phenol extraction (75 vol of freshly redistilled phenol and $25 \mathrm{vol}$ of $0.1 \mathrm{M}$ sodium acetate, $\mathrm{pH}$ 5.0). TyrosylBSMV RNA was recovered from the aqueous layer by precipitation with $2.5 \mathrm{vol}$ ethanol containing 20-30 mM sodium acetate, $\mathrm{pH} 4.5\left(-20^{\circ}\right)$. After centrifugation, the RNA pellet was washed with $70 \%$ ethanol, dissolved in water, and reprecipitated with ethanol- $\mathrm{Na}$ acetate. The final preparation was dissolved in $50 \mathrm{mM} \mathrm{Na}$ acetate, $\mathrm{pH} 5.0$, and stored at $-20^{\circ}$.

The acetylated derivatives of tyrosylBSMV RNA were prepared by the method of Lapidot et al. (1967).

Terminal oxidation of RNAs. Preparations of BSMV RNA Norwich and tRNA from wheat germ were both used in a concentration of $1 \mathrm{mg} / \mathrm{ml}$. Ten microliters of fresh $5 \mathrm{~m} M$ sodium metaperiodate were added to $50 \mu$ l of the aqueous RNA solution and the mixture was incubated in the dark for $30 \mathrm{~min}$ at room temperature. The RNA recovered after periodate oxidation was precipitated with 2.5 vol of ethanol with $\mathrm{Na}$ acetate $\left(-20^{\circ}\right)$.

Radioactivity measurements. Samples (10-100 $\mu \mathrm{l})$ were applied onto filter paper squares $(1 \times 1$ or $1.5 \times 1.5 \mathrm{~cm}$, Whatman $3 \mathrm{MM}$ ) and then washed successively with cold 10\% TCA, 5\% TCA, ethanol, and ether. The acid-precipitable radioactivity was determined as described previously (Agranovsky et al., 1978). The radioactivity of solutions was counted in a dioxane scintillation cocktail.

Affinity chromatography on oligo(dT)cellulose. Affinity chromatography was performed as described previously (Aviv and Leder, 1972). Tyrosylated and nonlabeled BSMV RNA or its fragments (see below) were dissolved in a high-salt buffer (0.5 $M \mathrm{NaCl} ; 10 \mathrm{mM}$ Tris-acetate, pH 5.07.6) and applied to an oligo(dT)-cellulose column (1-4 ml) equilibrated with 4-5 vol of the same buffer at $+10^{\circ}$. After standing 
for $0.5-1 \mathrm{hr}$ at $10^{\circ}$, the column was washed with the high-salt buffer until the background level of absorption at $260 \mathrm{~nm}$ or radioactivity was attained (elution of poly(A)- fraction). Elution of bound RNA (poly $(\mathrm{A})^{+}$fraction) was performed at $20^{\circ}$ with distilled water. The $\operatorname{poly}(\mathrm{A})^{-}$and $\operatorname{poly}(\mathrm{A})^{+}$fractions thus obtained were immediately precipitated by adding 2.5 vol of ethanol-Na acetate $\left(-20^{\circ}\right)$, as described previously (Agranovsky et al., 1978). In some experiments, tyrosyl-BSMV RNA was incubated in $75 \% \mathrm{DMSO} ; 25 \mathrm{mM} \mathrm{LiCl}$; $50 \mathrm{mM} \mathrm{Na}$ acetate, $\mathrm{pH} 5.0$, for $5 \mathrm{~min}$ at $37^{\circ}$. Then the RNA solution was diluted 10-fold with the high-salt buffer, applied to an oligo(dT)-cellulose column and chromatographed as described above.

Sucrose density gradient centrifugation. Samples of nonlabeled RNAs and RNA fragments were applied to $10-40 \%(\mathrm{w} / \mathrm{v})$ linear sucrose gradients buffered at $\mathrm{pH} 7.6$ with TEN buffer ( $20 \mathrm{~m} M$ Tris-acetate; 10 $\mathrm{m} M$ EDTA; $0.1 M \mathrm{NaCl}$ ) and centrifuged for $17-18 \mathrm{hr}$ at $38,000 \mathrm{rpm}$ at $+2^{\circ}$ in a SW41 rotor on a Beckman L5-50 ultracentrifuge.

To provide denaturing conditions during centrifugation, $5-20 \%(\mathrm{w} / \mathrm{v})$ sucrose gradients were made in $75 \%$ DMSO; $25 \mathrm{mM}$ $\mathrm{LiCl} ; 2 \mathrm{mM}$ EDTA, in 5-ml polyallomer tubes. The gradients were buffered with $10 \mathrm{~m} M$ Tris-acetate, $\mathrm{pH}$ 7.6. Samples were subjected to centrifugation for $42 \mathrm{hr}$ at $45,000 \mathrm{rpm}$ at $20^{\circ}$ in an SW50 rotor. Fractions $(0.25-0.5 \mathrm{ml})$ were collected by a Gilson Minipulse fraction collector equipped with ISCO Model UA5 absorbance monitor and Densi-Flow IIC (Buchler Instr.). Viral RNA or RNA fragments from the peak fractions were precipitated by adding 2.5 vol of ethanol- $\mathrm{Na}$ acetate $\left(-20^{\circ}\right)$.

Isolation of the polyadenylated fragments from BSMV RNA. From 0.5 to 0.8 mg of total BSMV RNA Norwich, or of its individual components (RNA 2 or RNA 3) were heated at $100^{\circ}$ for $10-20 \mathrm{~min}$ in $0.5-$ $1 \mathrm{ml}$ of distilled water. Then each sample was cooled on ice, buffered to $0.5 \mathrm{M} \mathrm{NaCl}$; $0.01 M$ Tris-acetate, $\mathrm{pH} 7.6$, and applied onto an oligo(dT)-cellulose column. The poly $(\mathrm{A})^{+}$fraction, containing polyadenylated RNA fragments of different sizes, was precipitated with ethanol-Na acetate.
The pellet was collected by centrifugation, dissolved in 100-150 $\mu$ l of distilled water, and applied to a sucrose gradient. The fragments were centrifuged and fractionated as described above. The 0.4-ml fractions corresponding to fragments of different size were separately mixed with 1 $\mathrm{ml}$ of ethanol-Na acetate $\left(-20^{\circ}\right)$. RNA was precipitated by centrifugation, dissolved in water, and stored at $-20^{\circ}$.

Agarose gel electrophoresis (AGE). BSMV RNA esterified with tyrosine was analyzed on tube gels $(0.6 \times 9 \mathrm{~cm})$ prepared as described by Lehrach et al. (1977). The gels contained $2 \%$ agarose, and were polymerized in $0.025 M$ citric acid ( $\mathrm{pH} 3.8$ ) with $6 M$ urea. Samples $(20-50 \mu l)$ containing

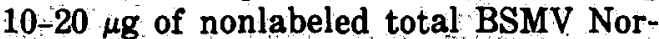
wich RNA, $\left[{ }^{3} \mathrm{H}\right]$ tyrosyl-RNA of the same viral strain $\left(1-2 \times 10^{4} \mathrm{cpm}\right), 0.1 \mathrm{~g} / \mathrm{ml}$ of sucrose, and $0.2 \mathrm{mg} / \mathrm{ml}$ of bromophenol blue, were applied to the gel and electrophoresis was performed at $0.4 \mathrm{~mA}$ per tube for $18 \mathrm{hr}$ at $4^{\circ}$. Gels were stained for 20 min in $0.2 \%$ methylene blue, $0.4 M \mathrm{Na}$ acetate, $\mathrm{pH} 5.0$, or with $1 \%$ ethidium bromide. Two-millimeter gel sections were sliced and incubated overnight at $37^{\circ}$ in scintillation vials with $0.3 \mathrm{ml}$ of $0.1 M$ NaCl; $2 \mathrm{~m} M$ EDTA; $20 \mathrm{~m} M$ Tris-acetate, $\mathrm{pH} 7.6$, then diluted with dioxane scintillation fluid and counted for radioactivity.

Synthesis of $\left[5^{\prime} .{ }^{39} P\right] p C p$ and $3^{\prime}$-terminal labeling of BSMV RNA components. [5'${ }^{32} \mathrm{PbCp}$ was synthesized from $3^{\prime}-\mathrm{CMP}$ in the reaction with polynucleotide kinase from bacteriophage T4-infected $E$. coli cells and $\left[\gamma^{-32} \mathrm{P}\right] \mathrm{ATP}$. Polynucleotide kinase isolated by a previously described method (Richardson, 1970) was kindly donated by $\mathrm{Dr}$. E. Sverdlov. The reaction mixture $(20 \mu \mathrm{l})$ consisted of $20 \mathrm{mM}$ Tris$\mathrm{HCl}, \mathrm{pH} 8.0 ; 10 \mathrm{mM} \mathrm{MgCl}_{2} ; 10 \mathrm{mM}$ dithiothreitol; 100 pmol [ $\left.\gamma{ }^{-92} \mathrm{P}\right] \mathrm{ATP} ; 100 \mathrm{pmol} 3^{\prime}-$ CMP, and 50 units/ml polynucleotide kinase. After incubation for $1 \mathrm{hr}$ at $37^{\circ}$, preparations of $\left[5^{\prime}{ }^{32} \mathrm{P}\right] \mathrm{pCp}$ with specific activities of $1500-1700 \mathrm{Ci} / \mathrm{mmol}$ were obtained and used without subsequent purification. Terminal labeling of BSMV RNA and poly $(\mathrm{A})^{+} 10 \mathrm{~S}$ mRNA from mouse plasmocytoma was performed essentially as described by England and Uhlenbeck (1978). The reaction mixture $(15 \mu l)$ con- 
tained $50 \mathrm{mM}$ Tris-HCl, pH 7.5; $10 \mathrm{mM}$ $\mathrm{MgCl}_{2} ; 10 \mathrm{mM}$ dithiothreitol; 10\% DMSO; $10 \mu \mathrm{g} / \mathrm{ml}$ bovine serum albumin; $5-10 \mathrm{pmol}$ RNA; 5-10 pmol [5'- $\left.{ }^{22} \mathrm{P}\right] p C p ; 100$ pmol ATP, and 260 units/ml RNA ligase. The preparation of RNA ligase isolated essentially by the method of Weiss et al. (1968) was obtained from Dr. S. Burd. After incubation for $15-17 \mathrm{hr}$ at $5^{\circ}$, the mixture was supplemented with $20 \mathrm{mM}$ EDTA and $20 \mu \mathrm{g}$ tRNA carrier, followed by phenol extraction and ethanol precipitation of RNA. RNA was pelleted by centrifugation and dissolved in $3 \mathrm{mM}$ EDTA; $80 \%$ formamide; $0.02 \%$ xylene cyanol-bromphenol blue. Preparations of ${ }^{82} \mathrm{P}$-labeled RNAs were incubated for $1 \mathrm{~min}$ at $75^{\circ}$ and then subjected to electrophoresis in $3 \%$ polyacrylamide slab gels $(20 \times 20 \times 1 \mathrm{~cm})$ with $0.6 \%$ agarose in Tris-acetate buffer, $\mathrm{pH}$ 7.2. Electrophoresis was performed at 200 $\mathrm{V}, 70-90 \mathrm{~mA}$, for 4-5 $\mathrm{hr}$ until the xylene cyanol had migrated $10-11 \mathrm{~cm}$. After visualization by autoradiography, the zones corresponding to ${ }^{32} \mathrm{P}$-labeled RNA were sliced and eluted overnight with $1 \mathrm{mM}$ EDTA; $200 \mu \mathrm{g} / \mathrm{ml}$ tRNA at $37^{\circ}$. RNA was precipitated with ethanol, pelleted, and dissolved in $20 \mathrm{mM}$ Tris- $\mathrm{HCl}, \mathrm{pH} 7.5 ; 2$ MM EDTA.

Specific hydrolysis of ${ }^{\text {s2 }}$-labeled BSMV and mouse plasmocytoma poly $(A)^{+}$RNAs and analysis of the $S^{\prime}$-terminal oligonucleotides. This procedure was performed as described by Donis-Keller et al. (1977). [ $3^{\prime}$ $\left.{ }^{32} \mathrm{P}\right] \mathrm{RNA}$ was incubated for $1 \mathrm{hr}$ at $50^{\circ}$ with the following amounts of specific nucleases: 0.3 unit of $T_{1}$ RNase or $0.16 \mu \mathrm{g}$ of RNase $A$ or 1 unit of RNase $U_{2}$ were added to $6 \mu \mathrm{g}$ of RNA. The $3^{\prime}$-terminal fragments obtained after digestion of RNA by the nucleases were analyzed by electrophoresis in $25 \%$ polyacrylamide gels in Trisborate buffer with subsequent autoradiography (Donis-Keller et al., 1977; Negruk et al., 1979).

\section{RESULTS}

\section{Specificity of the Aminoacylation of BSMV} $R N A$

In the first series of experiments, the tritiated amino acid mixture (containing alanine, arginine, aspartic acid, glutamic acid, glycine, histidine, isoleucine, leucine, lysine, phenylalanine, proline, serine, threonine, tyrosine, and valine) was incubated in the wheat embryo aminoacylation system with RNAs from various sources. It was found that stimulation of ${ }^{3} \mathrm{H}$-amino acid incorporation into a complex with total BSMV Norwich RNA (fiveto six-fold over controls with ribosomal RNA or no RNA) is similar to that produced by TMV or BMV RNAs upon their aminoacylation (data not shown).

To determine the specificity of BSMV RNA aminoacylation, different individual amino acids were tested, e.g., the components of the amino acid mixture used above, and other amino acids (Table 1). All the amino acids used were active in the aminoacylation reaction with total tRNA (data not shown). From the results presented in Table 1 it is obvious that BSMV RNA can specifically accept tyrosine.

The next series of experiments was performed to illustrate the specificity of binding of tyrosine to BSMV RNA (strains Norwich and Russian) and BMV RNA. To this end, an excess of nonlabeled tyrosine or of a mixture of other 14 nonlabeled amino acids except tyrosine were added to the complete aminoacylation mixture containing 15 radioactive amino acids. It can be seen from Table 2 that unlabeled tyrosine specifically chases the radioactive label, competing with $\left[{ }^{3} \mathrm{H}\right]$ tyrosine for BSMV RNA aminoacylation. None of the 14 amino acids used was active in this respect. Only 3 of 20 common protein amino acids were not tested in our experiments, i.e., cysteine, asparagine, and tryptophan.

The second set of the results (Table 3) shows that tyrosylation of BSMV RNA is very similar to tyrosyl-BMV RNA and amino acyl-tRNA formation in cell-free systems (Lapidot et al., 1967; Oberg and Philipson, 1972; Hall et al., 1972). First, the tyrosyl-BSMV RNA complex formation strongly depends on the presence of ATP, viral RNA, and synthetases in the incubation mixture, as well as on the time of the reaction. Second, the synthesized product, tyrosyl-BSMV RNA, was relatively stable at acidic $\mathrm{pH}$ values, but was rapidly broken down at alkaline pH. Finally, the complex of acetyl-tyrosyl-BSMV RNA dis- 
TABLE 1

SPECIFicity OF AMnNOACYLATION OF BSMV RNA NORWICH WITH TYROSINE ${ }^{a}$

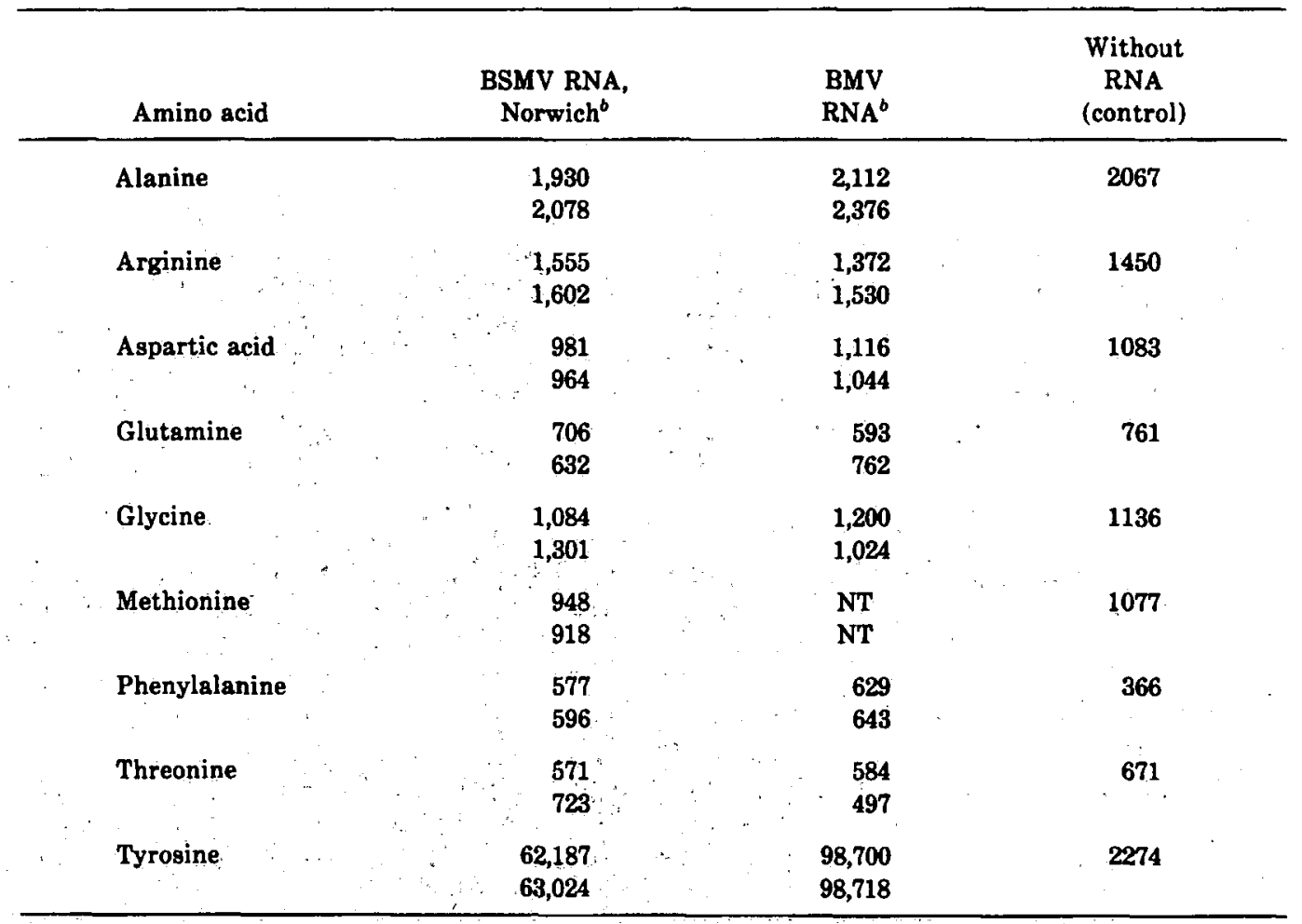

\footnotetext{
${ }^{a} 10 \mu \mathrm{Ci}$ of ${ }^{3} \mathrm{H}$-amino acid was added to each sample. Each figure represents TCA-insoluble radioactivity in $\mathrm{cpm} / 100 \mu \mathrm{l}$.

${ }^{b} 10 \mu \mathrm{g}$ of RNA was used for each test. The extent of binding was $0.31 \mathrm{~mol}$ of tyrosine/mol of BSMV RNA or $0.25 \mathrm{~mol}$ of tyrosine/mol of BMV RNA.
}

played improved stability upon incubation at pH 7.6 (Table 3). It can be seen that the extent of aminoacylation is variable (for example, cf. Tables 1 and 3). This is because several synthetase preparations were used in this study; the data in Table 1 were obtained with much more active enzymes than those in Table 3.

\section{Tyrosylation of Individual Genomic RNAs of the Two-Component and the Three- Component BSMV Strains}

The total RNA preparations isolated from two-, three-, and four-component strains Russian, Norwich, and Argentina Mild could bind tyrosine in the aminoacylation system (see Tables 2 and 5). The data presented in Table 4 show that all individual RNA components of BSMV Norwich and Russian accept tyrosine.

\section{Binding of Tyrosyl-BSMV RNA to Oligo- (dT)-Cellulose}

In accordance with our previous data (Agranovsky et al., 1978) it can be seen from Fig. 1 that native BSMV RNA Norwich can be separated into poly $(A)^{-}$and poly $(\mathrm{A})^{+}$fractions upon chromatography on oligo(dT)-cellulose. It seemed reasonable to consider only poly(A)-deficient but not $3^{\prime}$-polyadenylated molecules of BSMV RNA as aminoacylation candidates. However, it was found that the larger part of tyrosylated BSMV RNA can be bound to oligo(dT)-cellulose and then eluted (Fig. 1). It is of importance that incubation of 
TABLE 2

SPECIFICITY OF COMPETITION OF UNLABELED TYROSINE FOR AMINOACYLATION OF BSMV RNA

\begin{tabular}{|c|c|c|}
\hline $\begin{array}{l}\text { RNA isolated } \\
\text { from }\end{array}$ & $\begin{array}{c}\text { Complete } \\
\text { mixture } \\
+ \text { nonlabeled } \\
\text { tyrosine }^{a}\end{array}$ & $\begin{array}{c}\text { Complete } \\
\text { mixture } \\
+ \text { nonlabeled } \\
\text { amino acid } \\
\text { mixture } \\
\text { without } \\
\text { tyrosine }^{b}\end{array}$ \\
\hline BSMV Norwich ${ }^{c}$ & $\begin{array}{l}1789 \\
1759\end{array}$ & $\begin{array}{l}4283 \\
4339\end{array}$ \\
\hline BSMV Russianc & $\begin{array}{l}1763 \\
1738\end{array}$ & $\begin{array}{l}4452 \\
4653\end{array}$ \\
\hline BMV & $\begin{array}{l}1639 \\
1590\end{array}$ & $\begin{array}{l}5435 \\
5716\end{array}$ \\
\hline $\begin{array}{l}\text { Without RNA } \\
\text { (control) }\end{array}$ & 1489 & 1115 \\
\hline
\end{tabular}

Note. Each sample was supplemented with $10 \mu \mathrm{C}$ of the mixture of $15^{3} \mathrm{H}$-amino acids and (a) with an excess of nonlabeled tyrosine $(20 \mathrm{nmol})$ or $(\mathrm{b})$ of 14 nonlabeled amino acids except tyrosine ( $20 \mathrm{nmol}$ of each amino acid in the mixture). Each figure represents TCA-insoluble radioactivity in $\mathrm{cpm} / 100 \mu$ l. (C) $10 \mu \mathrm{g}$ of RNA were used for each test.

tyrosyl-BSMV RNA under denaturing conditions (75\% DMSO; $25 \mathrm{mM} \mathrm{LiCl,} \mathrm{pH}$ 5.0) prior to chromatography had no effect on the binding ability of $\left[{ }^{3} \mathrm{H}\right]$ tyrosylated BSMV RNA to oligo(dT)-cellulose (Fig. 1).

These observations were further strengthened by the in vitro aminoacylation of preparations of $\operatorname{poly}(\mathrm{A})^{-}$and $\operatorname{poly}(\mathrm{A})^{+}$ BSMV RNA (Table 5). It can be concluded from the data presented in Table 5 that both $\operatorname{poly}(\mathrm{A})^{+}$and poly(A)- fractions of BSMV RNA Norwich and Argentina Mild can accept tyrosine.

\section{Inhibition of Aminoacylation of BSMV RNA by Terminal Oxidation}

It was mentioned above that a tRNAlike structure can be localized either at the 3 '-end (several plant viruses) or internally (some picornaviruses) in the virion RNA molecule. It is known that specific chemical modification of terminal $2^{\prime}, 3^{\prime}$-diol groups (oxidation with sodium metaper- iodate) can affect only external tRNA-like structures in viral genomes (Shih et al., 1974) and has no effect on the internal aminoacylatable sequences (Lindley and Stebbing, 1977). It can be seen from Table 6 that preparations of BSMV RNA Norwich and tRNA (taken as a control) treated with sodium metaperiodate have a much lower ability of accepting tyrosine.

\section{Aminoacylation of BSMV RNA after Gra dient Centrifugation under Denatur- ing Conditions}

In separate experiments, BSMV RNA was subjected to sucrose density gradient centrifugation under denaturing conditions to obtain high-molecular-weight virion RNA free of associated tRNA(s) if the latter should be present in RNA preparations. It was reported by Chumakov (1979) that even poly(G).poly(C) hybrids melted completely at room temperature in the presence of $75 \%$ DMSO and $25 \mathrm{mM}$ $\mathrm{LiCl}$. In control experiments (data not shown) we demonstrated that ${ }^{3} \mathrm{H}$-labeled polyuridylic acid can be liberated from the preformed complex with BSMV RNA during centrifugation under these conditions (see Materials and Methods). The data in Table 5 show that BSMV RNA Norwich [the total preparation as well as a poly $(\mathrm{A})^{+}$ fraction] retained its tyrosine-accepting activity after being passed through the denaturing gradient indicating that this activity was not due to associated tRNA.

\section{Analysis of Tyrosyl-BSMV RNA by Aga- rose Gel Electrophoresis}

The above experiments appeared to exclude the presence of a tyrosine-accepting tRNA noncovalently bound to the BSMV genome. To provide additional evidence against the existence of associated lowmolecular-weight acceptor, the acetyl-tyrosyl-BSMV RNA Norwich was subjected to agarose gel electrophoresis (AGE) at pH 3.8 in the presence of $6 M$ urea (Lehrach et al., 1977). These denaturing conditions were most suitable for the analysis of aminoacylated RNA because of the stability of the aminoacylester bound at low 
TABLE 3

REQUIREMENTS FOR THE AMINOACYLATION OF BSMV RNA AND STABILITY OF TYROSYL-BSMV RNA ${ }^{a}$

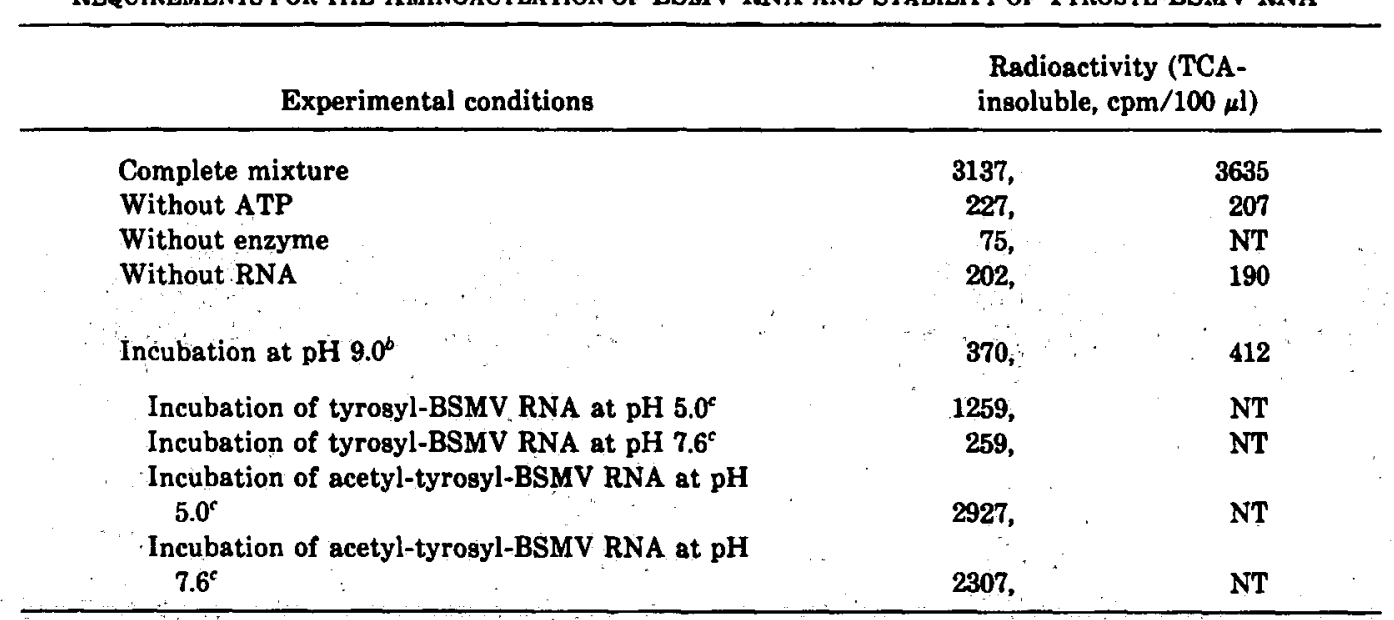

"Samples were supplemented with $2.5 \mu \mathrm{Ci}$ of $\left[{ }^{8} \mathrm{H}\right]$ tyrosine: $5 \mu \mathrm{g}$ of total RNA from BSMV Norwich was used for each test.

${ }^{b}$ After $30 \mathrm{~min}$ incubation at $30^{\circ}$ the reaction mixture was adjusted to $\mathrm{pH} 9.0$ with $\mathrm{KOH}$ and incubated for $15 \mathrm{~min}$.

'Preparations of tyrosyl and acetyl-tyrosyl-BSMV RNAs were incubated at $30^{\circ}$ for $2 \mathrm{hr}$ in a $50 \mu \mathrm{l}$ of 50 $\mathrm{m} M$ Na acetate, $\mathrm{pH} 5.0$, or $50 \mathrm{mM}$ Tris-acetate, $\mathrm{pH}$ 7.6. The extent of deacylation was determined by the filter paper disk assay (see Materials and Methods).

pH (Hall et al., 1972; Lapidot et al., 1967). It can be seen from Fig. 2 that the bulk of the tyrosine label migrated together with RNA 3 of BSMV Norwich upon electrophoresis, the minor peaks correspond-

\section{TABLE 4}

AMINOACYLATION OF INDIVIDUAL GENOMIC RNA COMPONENTS OF BSMV STRAINS NORWICH AND RUS. SIAN

\begin{tabular}{llr}
\hline & \multicolumn{1}{c}{$\begin{array}{c}\text { Radioactivity } \\
\text { (TCA-insoluble, } \\
\text { cpm/100 } \mu \text { l) }\end{array}$} \\
\hline BSMV RNA Norwich & & \\
RNA 1 & $3995^{a}$ & \\
RNA 2 & 4234, & 4736 \\
RNA 3 & 4653, & 6016 \\
BSMV RNA Russian & & \\
RNA 1 & 1145 & \\
RNA 2 & 2746, & 2550 \\
Without RNA (control) & 122, & 126 \\
\hline a 0.5 $\mu$ Ci of [ ${ }^{3}$ H]tyrosine and 5 & $\mu \mathrm{g}$ of RNA were \\
added to each sample. &
\end{tabular}

ing to the first two genomic components (RNAs 1 and 2) of this strain were also resolved. The lower extent of tyrosylation of RNAs 1 and 2 as compared to RNA 3 can be explained by their relatively lower molar content in total RNA Norwich (Agranovsky et al., 1978). It seems reasonable to suggest that the presence of tyrosylated RNA fragments migrating faster than RNA 3 Norwich (Fig. 2) is due to partial degradation of RNA during incubation in the cell-free aminoacylation system. The same results were obtained upon electrophoresis of tyrosylated $\operatorname{poly}(\mathrm{A})^{+}$ BSMV RNA Norwich (data not shown). These data suggest that amino acid-accepting activity was associated with the full-length RNA components of the BSMV genome.

Attempt to Localize the tRNA-like Structure in BSMV RNA Components

Preparations of the individual RNA components of BSMV Norwich (RNA 2 and RNA 3) constituting about $80 \%$ of the to- 
TABLE 5

Tyrosylation of Poly(A) ${ }^{+}$and POLY(A)- Fractions of BSMV RNA

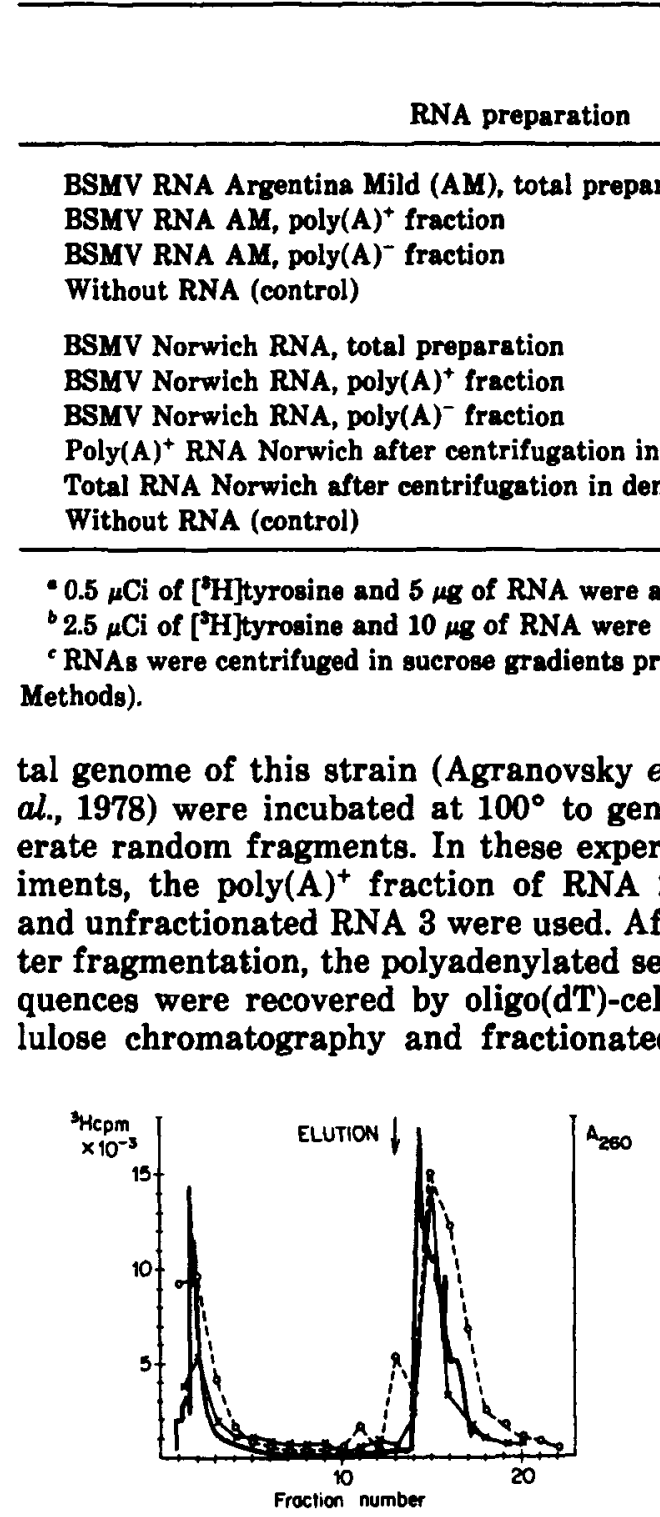

FIG. 1. Oligo(dT)-cellulose chromatography of: native nonlabeled BSMV RNA Norwich (solid line represents elution profile registered at $260 \mathrm{~nm}$ ), $\left[{ }^{3} \mathrm{H}\right]$ tyrosyl-BSMV RNA $\left(\mathrm{O},{ }^{2} \mathrm{H} \mathrm{cpm}\right)$, and [ $\left.{ }^{2} \mathrm{H}\right]$ tyrosy]BSMV RNA incubated in 75\% DMSO; $25 \mathrm{mM} \mathrm{LiCl}$; $50 \mathrm{mM} \mathrm{Na}$ acetate, $\mathrm{pH} 5.0$, for $5 \mathrm{~min}$ at $37^{\circ}$ prior to applying on a column $\left(X,{ }^{8} \mathrm{H} \mathrm{cpm}\right)$. BSMV RNA Norwich was incubated in $200-400 \mu$ l of complete aminoacylation mixture in the presence of $\left[{ }^{2} \mathrm{H}\right]$ tyrosine and then extracted with phenol. Tyrosyl-RNA was recovered by three or four cycles of ethanol precipitation (for details, see Materials and Methods). by sucrose density gradient centrifugation. The $\operatorname{poly}(\mathrm{A})^{+}$fragments of RNA 2 and 3 were positioned in sucrose gradients between two markers, tRNA and RNA 4 of BMV, which were centrifuged in sister gradients (Fig. 3). Amino acid-accepting activity of different gradient fractions (i.e., of the polyadenylated BSMV RNA fragments of different length) was tested. The data presented in Table 7 indicate that even the relatively short polyadenylated sequences from fractions 6-7 are able to accept tyrosine. The molecular weights of

TABLE 6

INHIBITION OF TYROSYLATION OF BSMV RNA BY TERMINAL OXIDATION WITH SODIUM METAPERIODATE

\begin{tabular}{|c|c|c|}
\hline \multirow[b]{2}{*}{$\begin{array}{l}\text { BSMV Norwich RNA, total } \\
\text { preparation } \\
\text { BSMV Norwich RNA }{ }^{b}{ }^{b} \\
\text { tRNA from wheat embryos } \\
\text { tRNA }{ }^{b}{ }^{b} \\
\text { Without RNA (control) }\end{array}$} & \multicolumn{2}{|c|}{$\begin{array}{l}\text { Radioactivity } \\
\text { (TCA-insoluble, } \\
\text { cpm/100 } \mu \mathrm{l})^{a}\end{array}$} \\
\hline & $\begin{array}{r}3000, \\
642, \\
2168, \\
620, \\
66,\end{array}$ & $\begin{array}{r}2662 \\
616 \\
2021 \\
683 \\
93\end{array}$ \\
\hline
\end{tabular}

${ }^{2} 0.5 \mu \mathrm{Ci}$ of $\left[{ }^{3} \mathrm{H}\right]$ tyrosine and $5 \mu \mathrm{g}$ of RNA were added to each sample.

${ }^{\circ}$ RNA treated with sodium metaperiodate. 


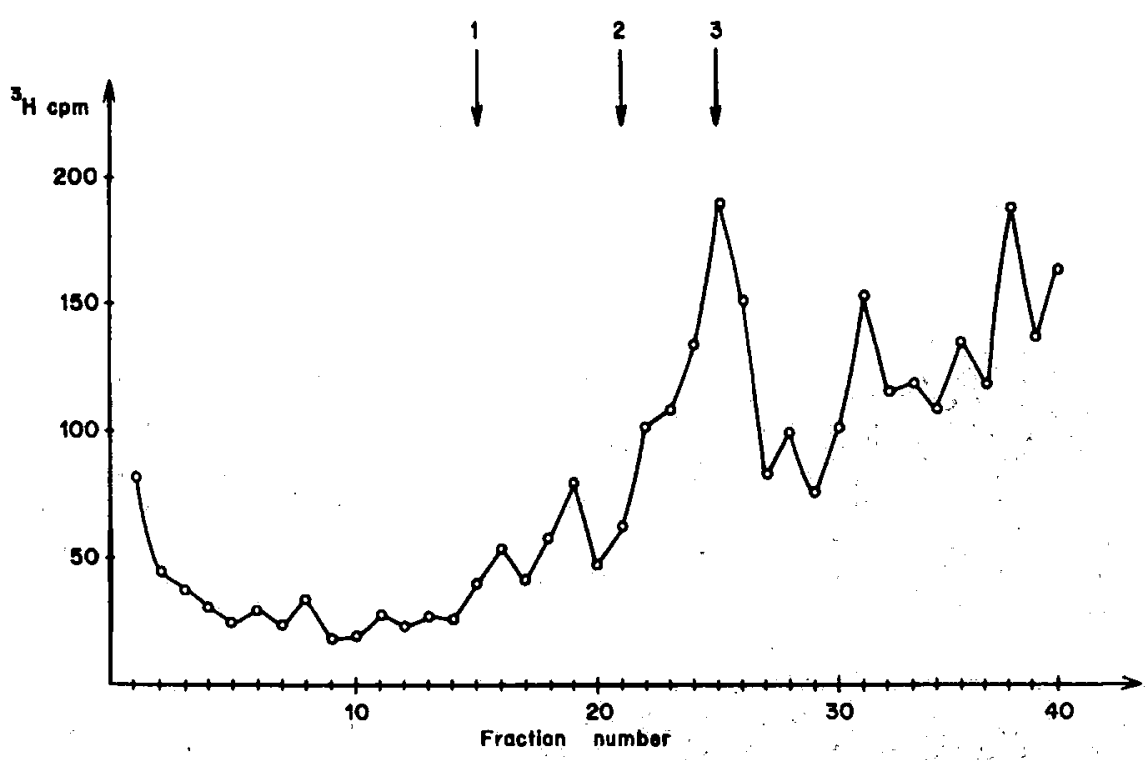

FIG. 2. Electrophoresis of an acetyl $-\left[^{8} \mathrm{H}\right]$ tyrosyl-BSMV RNA preparation in a $3 \%$ agarose gel at pH 3.8 in the presence of $6 M$ urea. Preparation of native nonlabeled RNA Norwich $(10 \mu g)$ was mixed with $10-15 \times 10^{3} \mathrm{cpm}$ of $\left[{ }^{3} \mathrm{H}\right]$ tyrosylated and acetylated RNA of the same strain and then applied on the gel. The zones corresponding to the positions of the BSMV RNA components were visualized by staining with either ethidium bromide or methylene blue. Gels were sliced and counted as described under Materials and Methods. Arrows correspond to marker BSMV RNA components RNA 1, 2, and 3, respectively.

these RNA fragments can be roughly estimated at 4-6 $\times 10^{4}$ (about $150-200 \mathrm{nu}$ cleotides) from the log molecular weight mobility plot based on the mobilities of tRNA (MW $\left.2.5 \times 10^{4}\right)$, BMV RNA $4(0.28$ $\left.\times 10^{6}\right)$, BMV RNA $3\left(0.8 \times 10^{6}\right)$, and BMV RNAs 1 and $2\left(0.99-1.09 \times 10^{6}\right)$ in sucrose gradients (Lane and Kaesberg, 1971). It can also be seen from Table 7 that BSMV RNA fragments of the size of tRNA (fractions 4-5) were probably devoid of accepting activity. The similar distribution was obtained in analogous experiments with the total RNA from BSMV Norwich (data not shown).

\section{Analysis of the $3^{\prime}$-Terminal Oligonucleo- tides Derived from $\boldsymbol{S}^{\prime}{ }^{32} P$-Labeled BSMV RNA Components}

It has been reported previously (Negruk et al., 1979) that incubation of BSMV RNA with RNases $T_{1}$ and $A$ under conditions when heteropolymeric sequences were completely digested yields poly(A) ${ }^{-}$frag- ments of 8-30 nucleotides in length. If these sequences were located directly at the 3 ' end of viral RNA molecules we could expect to reveal a set of fragments of heterogeneous size upon electrophoretic analysis of $T_{1}$ fragments of $3^{\prime}-{ }^{32} \mathrm{P}$-labeled BSMV RNA. Such size distributions were recently demonstrated by this method for a number of 3'-polyadenylated mRNAs from viruses and eukaryotes (Ahlquist and Kaesberg, 1979). With our experimental procedure, we can show size heterogeneity of $3^{\prime}$-terminal poly(A) in poly $(A)^{+}$ $10 \mathrm{~S}$ mRNA from mouse plasmocytoma cells taken as a control (Fig. 4a, b). However, analysis of complete $T_{1}$ digests of [ $\mathbf{3}^{\prime}$ ${ }^{32} \mathrm{P}$ ]pCp-labeled BSMV Argentina Mild RNA 1 (Fig. 4c) and BSMV Norwich RNA 3 (Fig. 4d) revealed no 3 '-poly(A) sequences. It can be seen from Fig. 4 that $\mathrm{T}_{1}$ digests of $3^{\prime}{ }^{32} \mathrm{P}$-labeled BSMV RNAs 1 and 3 contained two types of terminal sequences (tri- and tetranucleotides in $T_{1}$ digests). This result was further confirmed by the analysis of labeled products 


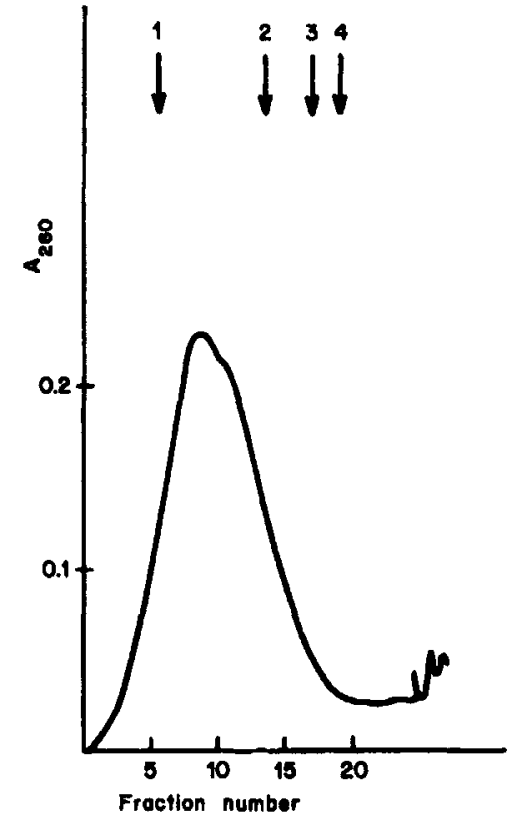

FIG. 3. Density gradient centrifugation of polyadenylated ("polar") fragments of BSMV Norwich RNA 3 obtained by incubation of native RNA 3 at $100^{\circ}$ for $15 \mathrm{~min}$ followed by oligo(dT)-cellulose chromatography and isolation of the $\operatorname{poly}(\mathrm{A})^{+}$fraction. The preparation of $\operatorname{poly}(A)^{+}$fragments was layered on a $10-40 \%(\mathrm{w} / \mathrm{v})$ sucrose gradient buffered at $\mathrm{pH} 5.0$ with $50 \mathrm{mM}$ Na acetate and centrifuged under the conditions given under Materials and Methods. UV absorption at $260 \mathrm{~nm}$ of the fractions was measured (solid line). Arrows correspond to marker RNA positions: 1, tRNA isolated from wheat embryos; 2 , BMV RNA 4; 3, BMV RNA 3; 4, BMV RNA 1 and 2. Sedimentation from left to right.

of RNAs 1 and 3 after hydrolyses with RNases $A$ or $\mathrm{U}_{2}$ (data not shown). Thus, the individual genomic components of BSMV contain two types of 3 '-terminal sequences both different from poly(A).

\section{DISCUSSION}

BSMV RNA can be specifically esterified with tyrosine in the presence of aminoacyl-tRNA synthetases from wheat embryos (see Tables 1 and 2). BSMV RNA appears to act in aminoacylation in vitro like BMV RNA and cellular tRNAs (see Table 3). Tyrosine-accepting activity has been found in all RNA components of two- component BSMV strain Russian, threecomponent strain Norwich, and in the total RNA from the Argentina Mild strain.

Tyrosylation of BSMV RNA is hardly consistent with the suggestion that poly(A) sequence is localized directly at the $3^{\prime}$ terminus of viral RNA (Agranovsky et al., 1978). Our results show that the tyrosineaccepting activity of BSMV RNA is not solely due to the poly $(A)^{-}$fraction of RNA (see Fig. 1 and Table 5). On the other hand, this activity cannot be ascribed to an internal tRNA-like structure or to noncovalently associated tRNA ${ }^{\mathrm{Ty}}$, but is present in the "open" state at the 3 ' end of intact poly(A) ${ }^{+}$or poly(A) ${ }^{-}$BSMV RNA (see Fig. 2 and Table 6). It must be mentioned that both tRNA-like structure and the poly(A) sequence are combined in a fragment of RNA containing 150-200 nucleotides (Table 7). One can assume that a poly(A) sequence is intercalated between the coding $5^{\prime}$ region of BSMV RNA and a 3 '-terminal tyrosine-accepting structure. This conclusion is in agreement with our results indicating the absence of $\operatorname{poly}(\mathrm{A})$ from the $3^{\prime}$ end of BSMV RNAs 1 and 3 and the presence of two types of $3^{\prime}$-terminal sequences in each of these RNAs (Fig. 4c, d).

It has been suggested previously (Agranovsky et al., 1978), that the poly(A) sequence is localized at the $3^{\prime}$ end of BSMV RNA. This suggestion was based on the fact that RNase-resistant fragments of BSMV RNA contained about $100 \%$ adenosine and about $50 \%$ of a terminal tritium label was retained in the RNase-resistant (i.e., $\operatorname{poly}(A)$ as was suggested) fragments obtained after digestion of poly (A $)^{+}$BSMV RNA with RNases $A$ and $T_{1}$ (Agranovsky et al., 1978). It is of importance that the content of adenosine in the RNase-resistant fragments of BSMV RNA depended on the conditions of nuclease digestion, varying from $43 \%$ in mild conditions (i.e., in a high-salt buffer at $30-37^{\circ}$ ) to 91 , and even to $99.9 \%$ in drastic conditions (i.e. when the incubation mixture was heated at $100^{\circ}$ for a short time) (Negruk et al., 1979). Therefore we have suggested that the RNase-resistant fragment obtained after mild hydrolysis contained, besides a poly(A) sequence, a certain piece of 
TABLE 7

AMINOACYLATION OF POLY(A) ${ }^{+}$BSMV RNA FRaGMENTS OF DIFFERENT LENGTHS

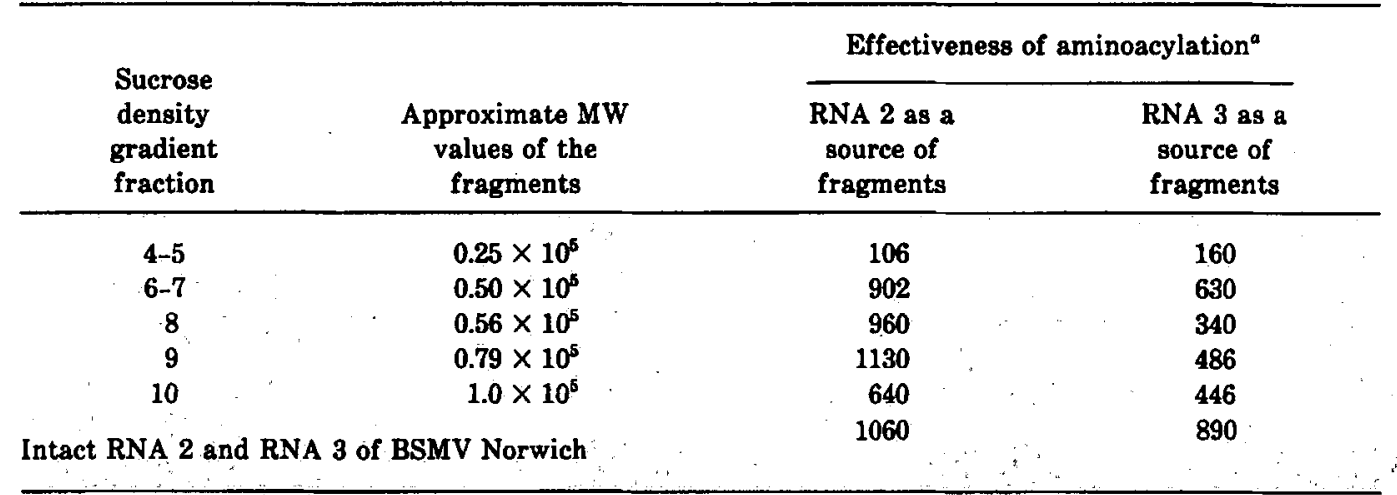

a Each figure represents TCA-insoluble radioactivity in cpm/1 $\mu \mathrm{g}$ of RNA. $5 \mu \mathrm{g}$ of RNA was used for each test.

BSMV RNA forming a hairpin structure which survives digestion (Negruk et al., 1979). The conditions of specific hydrolysis of $\left[3^{\prime}-{ }^{32} \mathrm{P}\right] p C \mathrm{p}$-labeled BSMV RNAs used in this study should be referred to as drastic since the terminal labeling of polynucleotides was performed in the presence of DMSO and incubation with nucleases was carried out at $50^{\circ}$ in a low-salt buffer (see Materials and Methods). These conditions allowed us to digest the 3 '-terminal tRNA-like structure of BSMV RNA and to liberate two short oligonucleotides labeled with $\left[{ }^{22} \mathrm{P}\right] \mathrm{pCp}$ (see Fig. 4).

On the whole, these studies suggest that the preparations of individual BSMV RNAs are composed of molecules differing in their $3^{\prime}$-terminal sequences. First, this population contains poly(A) ${ }^{+}$and $\operatorname{poly}(\mathrm{A})^{-}$ molecules each possessing the 3 '-terminal tyrosine-accepting structure; second, the $3^{\prime}$ end of BSMV RNA is represented by two different types of oligonucleotides (see Fig. 4). It is important that both poly(A) ${ }^{+}$ and $\operatorname{poly}(\mathrm{A})^{-}$fractions of BSMV RNA were equally infective (Agranovsky et al., 1978). This fact allows one to suggest that the poly (A) sequence in not essential for BSMV RNA replication and translation and that it is synthesized post-transcriptionally. Such an explanation could be accepted if the poly(A) track is localized directly at the $3^{\prime}$ end of BSMV RNA. However, evidence is presented here show- ing that the poly(A) sequence precedes a tRNA-like structure in poly $(\mathrm{A})^{+}$BSMV RNA. Hence, one could ask: are both the poly(A) sequence and the tRNA-like structure synthesized post-transcriptionally? The heterogeneity of the $3^{\prime}$-terminal sequences in BSMV RNA molecules can hardly be explained if only template copying operated in BSMV RNA synthesis. It is of importance in this respect to know whether the plus strands of the doublestranded BSMV RNA replicative form contain poly(A) and can accept tyrosine, and whether its minus strand contain polyuridylic acid tracts. Capped eukaryotic mRNAs have been recently shown to stimulate transcription of influenza virus RNA both in vivo and in vitro by the transfer of their cap structure plus the adjacent nucleotides to the virus transcript (for example, see Robertson et al., 1980). We cannot exclude that the tyrosine-accepting structure of BSMV RNA represents a cellular tRNA ${ }^{\text {Tyr }}$ ligated to poly(A) ${ }^{+}$and poly(A) ${ }^{-}$viral RNAs. If the accepting sequence in BSMV RNA is virus coded, the different 3 '-terminal sequences can also be synthesized by a splicing mechanism, which would involve joining of one RNA segment to another by the action of an RNA ligase.

Thus, different structural forms of viral RNA molecules can be delineated: (1) RNAs containing a $3^{\prime}$-terminal poly (A) 
186

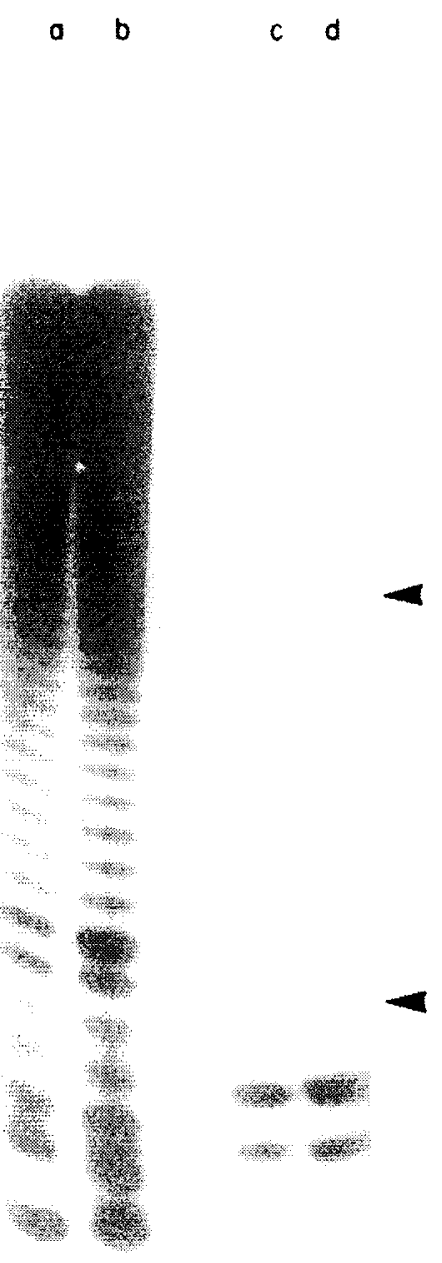

FIG. 4. Electrophoregram of the complete $T_{1}$ RNase digests of $3^{\prime}-{ }^{22} \mathrm{P}$-labeled RNAs in $25 \%$ polyacrylamide gel run with Tris-borate buffer, $\mathrm{pH}$ 8.3, containing $7 M$ urea. After the completion of electrophoresis, the gel was treated and autoradiographed as described previously (Donis-Keller et al., 1977). (a, b) $10 \mathrm{~S}$ poly(A)-containing RNA from mouse plasmocytoma. (c) BSMV RNA 1 (strain Argentina Mild). (d) BSMV RNA 3 (strain Norwich). Arrows indicate the positions of bromphenol blue (lower) and xylene cyanol (upper) dyes.

sequence (RNAs of CPMV, togaviruses, and potyviruses; for review, see Atabekov and Morozov, 1979); (2) RNAs containing a 3'-terminal tRNA-like structure (RNAs of TMV, TYMV, and BMV); (3) RNAs containing a 3 '-terminal poly (A) sequence and internal tRNA-like structure (RNAs of mengo- and EMC viruses); and (4) RNAs containing the $3^{\prime}$-terminal tRNA-like structure preceded by an internal poly(A) sequence (BSMV RNA).

\section{ACKNOWLEDGMENTS}

We express our appreciation to Dr. M. K. Brakke for sending the Argentina Mild strain of BSMV and to Dr. V. K. Novikov for supplying us with TMV and BMV preparations. The authors are grateful to $\mathrm{Dr}$. A. A. Bogdanov for helpful discussions and comments, and to Mr. A. V. Galkin for the assistance in translating the text.

\section{REFERENCES}

Agranovsky, A. A., DoLJA, V. V., KaVSAN, V. M. and ATABEKoV, J. G. (1978). Detection of polyadenylate sequences in RNA components of barley stripe mosaic virus. Virology 91, 95-105.

Agranovsky, A. A., DolJa, V. V., Kagramanova, V. K., and ATABEKov, J. G. (1979). The presence of a cap structure at the $5^{\prime}$-end of barley stripe mosaic virus RNA. Virology 95, 208-210.

Ahlquist, P., and KaEsBerg, P. (1979). Determination of the length of $\operatorname{poly}(A)$ at the 3 terminus of the virion RNAs of EMC virus, poliovirus, rhinovirus, RAV-61 and CPMV and of mouse globin mRNA. Nucleic Acids Res. 7, 1195-1204.

ATABEKov, J. G., and MOROzov, S. Yu. (1979). Translation of plant virus messenger RNAs. Advan. Virus Res. 25, 1-91.

AvIV, H., and LEDER, P. (1972). Purification of biologically active globin messenger RNA by chromatography on oligothymidylic acid-cellulose. Proc. Nat. Acad. Sci USA 69, 1408-1422.

Bastin, M., Dasgupta, R., Hall, T. C., and KaesBERG, P. (1976). Similarity in structure and function of the 3 '-terminal region of the four brome mosaic virus RNAs. J. Mol Biol. 103, 737-745.

BEACHY, R. N., ZaitLIN, M., BRUENING, G., and IsRAEL, H. W. (1976). A genetic map of the cowpea strain of TMV. Virologn 73, 498-507.

Chumakov, K. M. (1979). Studies on melting and reassociation of double-stranded encephalomyocarditis virus RNA. Biolkhimiya 44, 57-65.

DiNatale, P., and Eilat, D. (1976). Patterns of $E$. coli leucine tRNA isoacceptors following bacteriophage MS2 infection. Nucleic Acids Res 3, 917-930.

DOLA, V. V., NEGRUK, V. I., NOVIKOV, V. K., and ATABEKov, J. G. (1977). A simple method for isolating pure RNA preparations after electrophoresis in polyacrylamide gel. Anal Biochem. 80, 502506.

Donis-Keller, H., MaxAM, A. M., and Gllbert, W. (1977). Mapping adenines, guanines and pyrimidines in RNA. Nucleic Acids Res 4, 2527-2538. 
England, T. E., and Uhlenbeck, O. C. (1978). 3'Terminal labeling of RNA with T4 RNA ligase. Nature (London) 275, 560-561.

HALL, T. C. (1979). Transfer RNA-like structures in viral genomes. In "International Review of Cytology" (G. H. Bourne and J. F. Danielli, eds.), Vol. 60, pp. 1-26. Academic Press, New York.

HALL, T. C., SHIH, D. S., and KAESBERG, P. (1972). Enzyme-mediated binding of tyrosine to brome mosaic virus RNA. Biochem. J. 129, 969-976.

JACKSON, A. O., and BraKkE, M. K. (1973). Multicomponent properties of barley stripe mosaic virus RNA. Virology 55, 483-494.

KoHL, R. J., and HALL, T. C. (1974). Aminoacylation of RNA from several viruses: Amino acid specificity and differential activity of plant, yeast and bacterial synthetases. J. Gen. Virol. 25, 257-261.

LANE, L. C. (1974). The components of barley stripe mosaic and related viruses. Virology 58, 323-333.

LANE, L. C., and KaESBERg, P. (1971). Multiple genetic components in bromegrass mosaic virus. $\mathrm{Na}$ ture New Biol. 232, 40-43.

LAPIDOT, Y., DEGroOT, N., and FrY-ShafriR, I. (1967). Modified aminoacyl tRNA. II. A general method for the preparation of acylaminoacyl-tRNA Biochim. Biophys. Acta 145, 292-299.

LEhraCH; H., Diamond, D., WozNey, J. M., and BOEDTKER, H. (1977). RNA molecular weight determinations by gel electrophoresis under denaturing conditions, a critical reexamination. Biochemistry 16, 4743-4751.

LindLey, I. J. D., and Stebring, N. (1977). Aminoacylation of encephalomyocarditis virus RNA. $J$. Gen. Virol. 34, 177-182

NegruK, V. I., Agranovsky, A. A., Skrjabin, K. G., and ATABEKOV, J. G. (1979). Size determination of polyadenylate sequences in barley stripe mosaic virus RNA. Anal. Biochem. 99, 450-453.

OBERG, B., and PHILIPSON, L. (1972). Binding of histidine to tobacco mosaic virus RNA. Biochem. Biophys. Res. Commun. 48, 927-932.

PaLOMAR, M. K., BRAKKE, M. K., and JaCKSON, A. O. (1977). Base sequence homology in the RNAs of barley stripe mosaic virus. Virology 77, 471-480.

Pinck, M., GenevauX, M., and DuRanton, H. (1974). Studies on the amino acid acceptor activities of the eggplant mosaic viral RNA and its satellite RNA. Biochimie 56, 423-428.

PinCK, M., and HALL, T. C. (1978). Aminoacylation properties of eggplant mosaic virus RNA. Sepa- ration and association of tRNAs. Virology 88,281 285.

Pinck, M., Yot, P., Chapeville, F., and Duranton, H. M. (1970). Enzymatic binding of valine to the 3'-end of TYMV RNA. Nature (London) 226, 954956

RANDERATH, K., ROSENTHAL, L. J., and ZAMECHNIK, P. C. (1971). Base composition differences between avian myeloblastosis virus transfer RNA and transfer RNA isolated from host cells. Proc. Nat Acad. Sci. USA 68, 3233-3239.

RịCHARDSON, C. C. (1971). Polynucleotide kinase from Escherichia coli infected with bacteriophage T4. In "Procedures in Nucleic Acid Research" (G. L. Cantoni and D. R. Davies, eds.), pp. 815-828. Harper \& Row, New York.

Robertson, H. D., Dickson, E., Plotch, S. T., and KRUG, R. M. (1980). Identification of the RNA region transferred from a representative primer. $\beta$-globine mRNA, to influenza mRNA during in vitro transeription. Nucleic Acids Res. 8, 925-942.

ROSENTHAL, L. J., and ZAMECNIK, P. C. (1973). Amino acid acceptor activity of the " $70 \mathrm{~S}$-associated" $4 S$ RNA from avian myeloblastosis virus. Proc. Nat. Acad Sci USA 70, 1184-1185.

SALOMON, R., and LITTAUER, U. Z. (1974). Enzymatic acylation of histidine to mengovirus RNA. Nature New Biol. 249, 32-34.

ShiH, D. S., Kaesberg, P., and Hald, T. C. (1974). Messenger and aminoacylation functions of brome mosaic virus RNA after chemical modification of 3 '-terminus. Nature (London) 249, 353-355.

WANG, S., KOTHARI, R. M., TAYLOR, M., and HUNG, P. (1973). Transfer RNA activities of Rous sarcoma and Rous associated viruses. Nature New Biol 242, 133-135.

Weiss, B., Jacquemin-Sablon, A., Live, T. R., FAREED, G. C., and RICHARDSON, C. C. (1968). Enzymatic breakage and joining of deoxyribonucleic acid. VI. Further purification and properties of polynucleotide ligase from Escherichia coli infected with bacteriophage T4. J. Biol Chem. 243, 4543-4555.

Yot, P., Pinck, M., Haenni, A.-L., Duranton, H. M. and CHAPEviLLe, F. (1970). Valine-specific tRNAlike structure in tyrnip yellow mosaic virus RNA. Proc. Nat. Acad. Sci USA 67, 1345-1352.

ZAGORSKY, W. (1978). Preparation and characteristics of a wheat embryo cell-free extract active in the synthesis of high molecular weight viral polypeptides. Anal Biochem. 87, 316-333. 